\title{
PENERAPAN ASAS SEDERHANA, CEPAT, DAN BIAYA RINGAN TERHADAP PERKARA GUGATAN SEDERHANA DALAM SENGKETA EKONOMI SYARIAH (Analisis Terhadap Persyaratan Domisili Para Pihak)
}

\author{
Izzatun Tiyas Rohmatin \& Dian Berkah \\ Izza_fafa@yahoo.co.id
}

\begin{abstract}
Abstrak
Penyelesaian sengketa dengan acara sederhana telah meningkatkan kemudahan berusaha dan dapat memberikan akses lebih baik terhadap keadilan, termasuk dalam perkara ekonomi syariah di pengadilan agama. Sayangnya, persyaratan para pihak harus berdomisili sama menjadi kendala. Para pihak yang domisilinya berbeda yurisdiksi, tidak dapat diselesaikan dengan acara sederhana. Inilah yang melatarbelakangi penelitian ini. Rumusan masalah dalam penelitian dideskripsikan sebagai berikut. Pertama, apakah asas sederhana, cepat, dan biaya ringan berkaitan erat dengan perkara gugatan sederhana dalam sengketa ekonomi syariah? Kedua, apakah pengaturan domisili para pihak dalam gugatan sederhana dapat mewujudkan asas sederhana, cepat, dan biaya ringan? Ketiga, bagaimana bentuk formulasi pengaturan kriteria domisili para pihak pada gugatan sederhana sengketa ekonomi syariah?Jenis penelitian menggunakan penelitian pustaka dengan pendekatan kualitatif; metode pengumpulan datanya menggunakan metode dokumenter, sedangkan analisis datanya menggunkan metode analisis isi.

Hasil penelitian ini adalah, Pertama, penyelesaian melalui acara sederhana dalam sengketa ekonomi syariah merupakan implementasi asas sederhana, cepat, dan biaya ringan, sebaliknya asas sederhana, cepat, dan biaya ringan dapat diwujudkan dalam penyelesaian sengketa ekonomi syariah melalui acara sederhana. Kedua, asas sederhana, cepat, dan biaya ringan belum dapat diwujudkan dalam pengaturan domisili para pihak dalam Peraturan Mahkamah Agung RI Nomor 2 Tahun 2015 tentang Tata Cara Penyelesaian Gugatan Sederhana. Dan ketiga, formulasi pengaturan kriteria domisili para pihak pada gugatan sederhana perkara ekonomi syariah, dapat dirumuskan: (a) Penggugat dan Tergugat dalam gugatan sederhana berdomisili di daerah hukum pengadilan yang sama; (b) Apabila Para Pihak tidak berdomisili di daerah hukum yang sama, digunakan pemanggilan secara elektronik bagi pihak yang berada di luar wilayah pengadilan;
\end{abstract}

Kata kunci : Asas Sederhana, Cepat, Biaya Ringan, Gugatan Sederhana, Perkara Ekonomi Syariah, Domisili.

\section{PENDAHULUAN}


Undang-Undang Nomor 48

Tahun 2009 tentang Kekuasaan Kehakiman menetapkan bahwa peradilan, yang dimaknai sebagai suatu proses yang dijalankan di pengadilan yang berhubungan dengan tugas memeriksa, memutus dan mengadili perkara harus dilaksanakan dengaan asas sederhana, cepat dan biaya ringan (Pasal 2 Ayat (4)). Sederhana mengandung arti pemeriksaan dan penyelesaian perkara dilakukan dengan cara yang efisien dan efektif. Asas cepat, asas yang bersifat universal, berkaitan dengan waktu penyelesaian yang tidak berlarutlarut. Asas biaya ringan mengandung arti biaya perkara dapat dijangkau oleh masyarakat.

Namun dalam kenyataannya, tersebut dalam praktek peradilan belum dapat terwujud secara optimal. Meskipun ditengarai bukan disebabkan oleh sektor non hukum, namun penyebab tersebut tidak tunggal, sehingga permasalahannya menjadi kompleks. Menurut Ahmad Ali dan Wiwi Heryani, penyebabpenyebab non hukum tersebut meliputi faktor ekonomi, berupa keterbatasan fasilitas pengadilan, faktor politik, terindikasi dari belum terlihatnya upaya pemerintah untuk menambah anggaran pengadilan dan aparaturnya, serta faktor budaya yang terindikasi dari menguatnya kultur prestise yang mendorong orang berperkara mengedepankan unsur "gengsi" sehingga tidak mau mengalah dan tetap meneruskan upaya hukum meskipun sudah dinyatakan berkali-kali kalah oleh pengadilan (Ahmad Ali dan Wiwi Heryani, 2012 : 45)
Sementara itu, sengketa bisnis memerlukan penyelesaian secara cepat dan sederhana, sehingga biaya perkara relatif murah dengan hasil yang dapat diterima oleh kedua belah pihak tanpa menimbulkan masalah baru atau memperpanjang sengketa. Pada awalnya hukum acara yang digunakan untuk menyelesaikan sengketa bisnis menggunakan hukum acara perdata pada umumnya. Namun praktiknya, tidak semua sengketa bisnis diselesaikan dengan acara biasa. Salah satu penyebabnya adalah ketidaksesuaian antara nominal gugatan dengan biaya perkara dan penyelesaian perkara sehingga dirasakan asas sederhana, cepat, dan biaya ringan tidak dapat diimplementasikan dengan tepat.

Bank dunia melalui penelitiannya menyebutkan bahwa salah satu faktor penghambat dalam penyelesaian sengketa bisnis di Indonesia adalah "penyelesaian sengketa pada pengadilan tingkat pertama yang tidak efisien, jangka waktu penyelesaian yang lama, biaya perkara yang tinggi, dan serta biaya pengacara yang tinggi” (The Internasional Finance Corporate Indonesia, 2012 : 19).

Dari uraian di atas, maka dirasakan perlu adanya suatu bentuk prosedur penyelesaian sengketa (bisnis), seperti yang dikenal di negara-negara lain, yang mudah, murah dan cepat tetapi mempunyai kekuatan mengikat seperti putusan hakim. Salah satu caranya adalah memberikan kewenangan pada pengadilan untuk menyelesaikan perkara didasarkan pada besar kecilnya nilai objek sengketa, sehingga dapat tercapai penyelesaian 
sengketa secara cepat, sederhana dan murah, tetapi tetap dapat memberikan kekuatan hukum.

Dengan pertimbangan tersebut Mahkamah Agung kemudian menerbitkan Peraturan Mahkamah Agung Nomor 2 Tahun 2015 tentang Tata Cara Penyelesaian Gugatan Sederhana dalam upaya mewujudkan negara demokrasi modern dan meningkatkan pelayanan terbaik bagi masyarakat pencari keadilan.

Peraturan Mahkamah Agung ini terbit "untuk mempercepat proses penyelesaian perkara sesuai dengan asas peradilan sederhana, cepat, biaya ringan". Amran Suadi mengemukakan bahwa dari konsideran Peraturan Mahkamah Agung Nomor 2 Tahun 2015 tentang Tata Cara Gugatan Sederhana diketahui Mahkamah Agung memiliki keinginan dan tekad untuk mewujudkan asas sederhana, cepat, dan berbiaya ringan. Hal ini dimaksudkan untuk mereduksi stigma dan pandangan masyarakat umum bahwa penyelesaian perkara di pengadilan sangat rumit (Amran Suadi, $2018: 38$ ).

Di lingkungan peradilan agama, salah satu kewenangan Peradilan Agama sebagaimana diatur dalam Pasal 49 Undang-Undang Nomor 7 Tahun 1989 tentang Peradilan Agama sebagaimana diubah dengan Undang-Undang Nomor 3 Tahun 2006 dan UndangUndang Nomor 50 Tahun 2009 adalah sengketa ekonomi syariah. Ketentuan Pasal 49 huruf i UndangUndang Nomor 3 Tahun 2006 tersebut menyebutkan "Pengadilan Agama bertugas dan berwenang memeriksa, memutus, dan menyelesaikan perkara di tingkat pertama antara orang-orang yang beragama Islam di bidang ekonomi syariah".

Khusus terkait dengan penyelesaian sengketa ekonomi syariah, Mahkamah Agung telah mengeluarkan Peraturan Mahkamah Agung Nomor 14 Tahun 2016 tentang Tata Cara Penyelesaian Sengketa Ekonomi Syariah. Salah satu poin penting yang diatur dalam peraturan tersebut sebagaimana ketentuan Pasal 3 Ayat (2) adalah perkara ekonomi syariah yang nilainya paling banyak $\mathrm{Rp}$. 200.000.000,- (dua ratus juta rupiah) diperiksa dengan acara sederhana. Dan acara sederhana yang dimaksud dalam peraturan ini mengacu kepada Peraturan Mahkamah Agung Nomor 2 Tahun 2015 tentang Tata Cara Penyelesaian Gugatan Sederhana.

Adapun kriteria gugatan ekonomi syariah yang dapat diperiksa dengan acara sederhana, dapat dipahami sebagaimana berikut

\begin{tabular}{|c|c|c|}
\hline & $\begin{array}{l}\text { Tabe } \\
\text { riteria Gugats } \\
\text { m Sengketa E }\end{array}$ & $\begin{array}{l}\text { ederhana } \\
\text { omi Syariah }\end{array}$ \\
\hline $\begin{array}{l}\mathbf{N} \\
\mathbf{0}\end{array}$ & Aspek & Kriteria \\
\hline 1 & Nilai gugatan & $\begin{array}{l}\text { Paling } \\
\text { banyak Rp. } \\
200.000 .00 \\
0,-\quad \text { (dua } \\
\begin{array}{l}\text { ratus juta } \\
\text { rupiah) }\end{array}\end{array}$ \\
\hline 2 & $\begin{array}{l}\text { Domisili para } \\
\text { pihak }\end{array}$ & $\begin{array}{l}\text { Para pihak } \\
\text { harus } \\
\text { berdomisili } \\
\text { di wilayah } \\
\text { hukum } \\
\text { yang sama }\end{array}$ \\
\hline
\end{tabular}




\begin{tabular}{|c|c|c|}
\hline 3 & $\begin{array}{l}\text { Jumlah para } \\
\text { pihak }\end{array}$ & $\begin{array}{l}\text { Masing- } \\
\text { masing } \\
\text { pihak tidak } \\
\text { boleh lebih } \\
\text { dari satu, } \\
\text { kecuali } \\
\text { mempunyai } \\
\text { kepentingan } \\
\text { hukum } \\
\text { yang sama }\end{array}$ \\
\hline 4 & $\begin{array}{l}\text { Alamat } \\
\text { Tergugat }\end{array}$ & $\begin{array}{l}\text { Harus } \\
\text { diketahui }\end{array}$ \\
\hline 5 & $\begin{array}{l}\text { Pendaftaran } \\
\text { perkara }\end{array}$ & $\begin{array}{l}\text { Menggunak } \\
\text { an blanko } \\
\text { gugatan }\end{array}$ \\
\hline 6 & $\begin{array}{l}\text { Pengajuan } \\
\text { bukti }\end{array}$ & $\begin{array}{l}\text { Harus } \\
\text { bersamaan } \\
\text { dengan } \\
\text { pendaftaran } \\
\text { perkara }\end{array}$ \\
\hline 7 & $\begin{array}{l}\text { Pendaftaran } \\
\text { perkara, } \\
\text { penunjukan } \\
\text { hakim dan } \\
\text { panitera } \\
\text { sidang }\end{array}$ & $\begin{array}{l}\text { Maksimal } 2 \\
\text { hari }\end{array}$ \\
\hline 8 & $\begin{array}{l}\text { Pemeriksa } \\
\text { dan pemutus }\end{array}$ & $\begin{array}{l}\text { Hakim } \\
\text { tunggal }\end{array}$ \\
\hline 9 & $\begin{array}{l}\text { Pemeriksaan } \\
\text { pendahuluan }\end{array}$ & Ada \\
\hline 10 & Mediasi & Tidak ada \\
\hline 11 & $\begin{array}{l}\text { Kehadiran } \\
\text { para pihak }\end{array}$ & $\begin{array}{l}\text { Para pihak } \\
\text { wajib } \\
\text { menghadiri } \\
\text { setiap } \\
\text { persidangan } \\
\text { secara } \\
\text { langsung } \\
\text { (in } \\
\text { personal) } \\
\text { meski } \\
\text { mempunyai } \\
\text { kuasa } \\
\text { hukum }\end{array}$ \\
\hline 12 & $\begin{array}{l}\text { Konsekuensi } \\
\text { ketidakhadira }\end{array}$ & $\begin{array}{l}\text { Gugatan } \\
\text { dinyatakan }\end{array}$ \\
\hline
\end{tabular}

\begin{tabular}{|c|c|c|}
\hline & $\begin{array}{l}\text { n Penggugat } \\
\text { pada sidang } \\
\text { pertama tanpa } \\
\text { alasan yang } \\
\text { sah }\end{array}$ & gugur \\
\hline 13 & $\begin{array}{l}\text { Pemeriksaan } \\
\text { perkara }\end{array}$ & $\begin{array}{l}\text { Hanya } \\
\text { gugatan dan } \\
\text { jawaban }\end{array}$ \\
\hline 14 & $\begin{array}{l}\text { Batas waktu } \\
\text { penyelesaian } \\
\text { perkara }\end{array}$ & $\begin{array}{l}25 \text { hari } \\
\text { sejak sidang } \\
\text { pertama }\end{array}$ \\
\hline 15 & $\begin{array}{l}\text { Penyampaian } \\
\text { putusan }\end{array}$ & $\begin{array}{l}\text { Paling } \\
\text { lambat } 2 \\
\text { hari sejak } \\
\text { putusan } \\
\text { diucapkan } \\
\end{array}$ \\
\hline 16 & $\begin{array}{l}\text { Upaya hukum } \\
\text { dan batas } \\
\text { waktu } \\
\text { penyelesaiann } \\
\text { ya }\end{array}$ & $\begin{array}{l}\text { Keberatan } \\
\text { (7 hari sejak } \\
\text { Majelis } \\
\text { Hakim } \\
\text { ditetapkan) }\end{array}$ \\
\hline 17 & $\begin{array}{l}\text { Batas waktu } \\
\text { pendaftaran } \\
\text { upaya hukum }\end{array}$ & $\begin{array}{l}7 \text { hari sejak } \\
\text { putusan } \\
\text { diucapkan } \\
\text { atau } \\
\text { diberitahuk } \\
\text { an }\end{array}$ \\
\hline 18 & $\begin{array}{l}\text { Kewenangan } \\
\text { pengadilan } \\
\text { tingkat } \\
\text { banding dan } \\
\text { kasasi }\end{array}$ & Tidak ada. \\
\hline \multicolumn{3}{|c|}{$\begin{array}{l}\text { Sumber : diolah dari Peraturan } \\
\text { Mahkamah Agung Nomor } 2 \text { Tahun } \\
2015 \text { dan Nomor } 14 \text { Tahun } 2016 \\
\text { Diantara ketentuan kriteria } \\
\text { gugatan sederhana dalam sengketa } \\
\text { ekonomi syariah sebagaimana dalam } \\
\text { tabel di atas yang belum } \\
\text { mengedepankan asas sederhana, } \\
\text { cepat, dan biaya ringan adalah } \\
\text { kriteria domisili para pihak. Dalam } \\
\text { praktiknya, hal tersebut masih } \\
\text { memunculkan beberapa problem, } \\
\text { diantaranya adalah pertama, problem } \\
\text { filsafat, yaitu tidak tercapainya asas }\end{array}$} \\
\hline
\end{tabular}


sederhana, cepat dan biaya ringan dalam proses penyelesaian perkara.

Kedua, problem teoritis, yaitu pertentangan antara konsep sistem penyelesaian sengketa bisnis secara sederhana sehingga dapat mengedepankan asas sederhana, cepat, dan biaya ringan dengan kriteria domisili para pihak yang mengharuskan dalam satu wilayah yurisdiksi suatu pengadilan. Ketiga, problem yuridis, norma tentang domisili para pihak sebagai kriteria gugatan sederhana yang belum sepenuhnya mengedepankan asas sederhana, cepat, dan biaya ringan. Keempat, problem sosiologis yaitu tidak tercapainya asas kemanfaatan bagi upaya penyelesaian perkara sengketa ekonomi syariah yang berbasis pada asas sederhana, cepat, dan biaya ringan.

Kriteria yang mengharuskan para pihak berdomisili dalam satu wilayah dalam gugatan sederhana pada sengketa ekonomi syariah menjadikan penyelesaian sengketa ekonomi syariah pada umumnya belum bisa diselesaikan melalui proses penyelesaian gugatan sederhana. Pasalnya, tidak semua lembaga keuangan berkedudukan dalam setiap wilayah peradilan, sementara nasabah dari lembaga keuangan tersebut bisa jadi berasal dari wilayah yang berbeda dengan kedudukan lembaga keuangan tersebut, padahal nilai gugatannya relatif kecil. Dengan demikian hanya karena berbeda domisili, gugatan tersebut tidak dapat diajukan melalui proses gugatan sederhana.

\section{HASIL PENELITIAN DAN PEMBAHASAN}

\section{A. Keterkaitan Asas Sederhana, Cepat, dan Biaya Ringan dengan Perkara Gugatan Sederhana dalam Sengketa Ekonomi Syariah}

Dengan terbitnya Peraturan Mahkamah Agung Nomor 14 tahun 2016 tentang Tata Cara Penyelesaian Perkara Ekonomi Syariah, maka penyelesaian gugatan sederhana yang semula diatur dalam Peraturan Mahkamah Agung Nomor 2 Tahun 2015 tentang Tata Cara Penyelesaian Gugatan Sederhana dan hanya berlaku secara terbatas dalam sengketa perdata pada lingkungan peradilan umum, maka sesuai asas lex posterior derogat (legi) priori sekarang berlaku pula untuk penyelesaian sengketa ekonomi syariah pada yurisdiksi peradilan agama (Aaron X. Fellmeth \& Maurice Horwitz, 2018, http://www.oxfordreference.com, 9 Agustus 2018).

Gugatan sederhana atau dalam istilah popular disebut small claim court sebagaimana yang diatur dalam Peraturan Mahkamah Agung Nomor 2 Tahun 2015 tentang Tata Cara Penyelesaian Gugatan Sederhana merupakan prosedur penyelesaian sengketa perdata dengan beberapa syarat dan pembatasan tertentu dengan tujuan penyederhanaan proses agar penyelesaian perkara bisa lebih cepat yang diterapkan secara khusus bagi sengketa kontrak (wanprestasi) dan tuntutan kerugian akibat perbuatan melawan hukum (PMH) dengan nilai gugatan paling banyak $\mathrm{Rp}$ 200.000.000,- (dua ratus juta rupiah) mekanisme penyelesaian yang simple dan cepat dalam gugatan 
sederhana sangat menguntungkan bagi masyarakat dari kalangan menengah ke bawah untuk dapat mengajukan penyelesaian sengketanya ke pengadilan. (Ridwan Mansyur dan D.Y. Witanto, 2017: 12)

Keterkaitan antara asas sederhana, cepat, dan biaya ringan dengan perkara gugatan sederhana dalam sengketa ekonomi syariah dapat dipahami melalui latar belakang penerbitan dua peraturan Mahkamah Agung tersebut dimaksudkan untuk menjawab sorotan masyarakat ekonomi dunia yang menyangsikan Indonesia dapat menyelesaikan sengketa perkara bisnis secara sederhana, cepat, dan biaya ringan, karena Indonesia belum memiliki sistem small claim court. Karenanya dalam rangka menyongsong era perdagangan bebas ASEAN yang diprediksi akan banyak menimbulkan sengketa niaga/bisnis skala kecil yang berujung ke pengadilan dengan proses penyelesaian perkara yang mengedepankan asas sederhana, cepat, dan biaya ringan. Hatta Ali, Ketua Mahkamah Agung menyatakan bahwa Peraturan Mahkamah Agung yang mengatur tentang gugatan sederhana dimaksudkan untuk mempercepat proses penyelesaian perkara sesuai asas peradilan sederhana, cepat, biaya ringan. Hal itu dikeluarkan karena selama ini masyarakat pencari keadilan masih mengeluhkan lamanya proses berperkara di pengadilan.

Keterkaitan sebagaimana dikemukakan di atas, dalam perspektif teori maslahah yang menitikberatkan pada mewujudkan kemanfaatan atau menyingkirkan/ menghindari kemudaratan, maka dapat difahami bahwa diaturnya sistem gugatan sederhana dalam penyelesaian sengketa ekonomi syariah tersebut dimaksudkan untuk lebih mengedepankan perwujudan kemanfaatan dalam penyelesaian sengketa ekonomi syariah serta menghindari kemudaratan berupa berlarut-larutnya sistem penyelesaian sengketa dengan acara biasa yang berbelit-belit dan tidak menjamin kepastian hukum bagi pencari keadilan.

Indikator keterkaitan asas sederhana, cepat, dan biaya ringan dengan perkara sederhana dalam sengketa ekonomi syariah juga ditunjukkan dalam maksud dikeluarkannya dua Peraturan Mahkamah Agung tersebut, yaitu dimaksudkan sebagai salah satu cara mengurangi volume perkara di Mahkamah Agung. Keterkaitan itu juga ditunjukkan dalam proses yang ditunjukkan dalam pengajuan gugatan sederhana pada sengketa ekonomi syariah yang menunjukkan bahwa pengadilan sudah menyediakan formulir gugatan, jawaban, dan kesaksian (tanpa ada tuntutan provisi, eksepsi, rekonvensi, intervensi, replik, duplik, atau kesimpulan). Dengan demikian, proses persidangan dalam penyelesaian gugatan sederhana pada sengketa ekonomi syariah dapat memberikan kepastian hukum bagi para pencari keadilan karena tidak berbelit-belit.

Kemanfaatan dan kepastian hukum sebagaimana dimaksudkan pada sistem gugatan sederhana sebagaimana diatur dalam dua Peraturan Mahkamah Agung tersebut 
sesuai dengan dua dari tiga tujuan hukum yang dimaksudkan oleh Gustav Radbruch dalam teori tujuan hukumnya yaitu untuk mencapai kemanfaatan dan kepastian (Bernard L. Tanya, 2011 : 130). Kemanfaatan menunjuk pada memajukan kebaikan dalam hidup manusia, dalam konteks kajian ini maka pengaturan gugatan sederhana dalam penyelesaian sengketa ekonomi syariah sangat bermanfaat bagi masyarakat pencari keadilan. Sedangkan kepastian hukum menunjuk pada jaminan bahwa hukum benar-benar berfungsi sebagai peraturan yang ditaati, dalam konteks ini sistem penyelesaian perkara secara sederhana sangat menjamin kepastian hukum bagi para pihak berperkara, kepastian yang dijamin disini meliputi kepastian waktu, prosedur, dan kejelasan putusan yang akan diambil oleh hakim.

Asas sederhana dalam hukum acara perdata tersebut juga ditunjukkan dalam sederhananya alur penyelesaian gugatan sederhana dalam sengketa ekonomi syariah yang merupakan tahapan yang harus diperhatikan baik dari aspek kegiatan maupun jangka waktu yang diperlukan. Secara garis besar tahapan penyelesaian gugatan sederhana yang diatur dalam Peraturan Mahkamah Agung Nomor 2 Tahun 2015 tentang Tata Cara Penyelesaian Gugatan Sederhana dan Peraturan Mahkamah Agung Nomor 14 tahun 2016 tentang Tata Cara Penyelesaian Perkara Ekonomi Syariah, meliputi :

1) Pendaftaran;

2) Pemeriksaan kelengkapan gugatan sederhana;
3) Penetapan Hakim dan Penunjukan Panitera Pengganti;

4) Pemeriksaan Pendahuluan;

5) Penetapan Hari Sidang dan pemanggilan para pihak;

6) Pemeriksaan sidang dan perdamaian;

7) Pembuktian;

8) Putusan.

Dua Peraturan Mahkamah Agung tersebut di atas dalam konteks memenuhi kebutuhan penyelenggaraan praktik peradilan dapat dipahami memiliki relevansi dengan situasi serta kondisi hukum yang berkembang. Oleh karena itu peranan Perma terkadang menjelma sebagai pengisi kekosongan hukum, pelengkap berlakunya ketentuan undang-undang yang belum ada peraturan organiknya, sebagai sarana penemuan hukum, dan sebagai sumber hukum bagi hakim dalam praktik penegakan hukum.

Peraturan Mahkamah Agung Nomor 2 Tahun 2015 tentang Tata Cara Penyelesaian Gugatan Sederhana dan Peraturan Mahkamah Agung Nomor 14 tahun 2016 tentang Tata Cara Penyelesaian Perkara Ekonomi Syariah adalah bagian dari upaya mengisi kekosongan hukum yang tak pernah tersentuh oleh HIR/RBg. Dalam kaitan ini HIR/RBg tidak membedakan acara penyelesaian perkara perdata berdasarkan nilai material gugatan, padahal pembedaan ini sangat penting dan responsif terhadap kebutuhan adanya prosedur/acara penyelesaian yang lebih sederhana, cepat dan biaya ringan, terutama di dalam hubungan hukum keperdataan yang bersifat sederhana, 
Berdasarkan uraian di atas, maka dapat dipahami keterkaitan asas sederhana, cepat, dan biaya ringan dengan perkara gugatan sederhana dalam sengketa ekonomi syariah adalah sistem penyelesaian melalui acara sederhana dalam sengketa ekonomi syariah merupakan salah satu bentuk implementasi asas sederhana, cepat, dan biaya ringan dalam penyelenggaraan peradilan pada sengketa ekonomi syariah. Begitu pula sebaliknya, asas sederhana, cepat, dan biaya ringan dapat diwujudkan dalam penyelesaian sengketa ekonomi syariah melalui sistem penyelesaian gugatan sederhana (small claim court).

\section{B. Perwujudan Asas Sederhana, Cepat, dan Biaya Ringan dalam Pengaturan Domisili Para Pihak dalam Perkara Gugatan Sederhana}

Meskipun

Peraturan

Mahkamah Agung RI Nomor 2 Tahun 2015 tentang Tata Cara Penyelesaian Gugatan Sederhana sebagaimana diuraikan di atas sangat bermanfaat dan penting dalam percepatan penyelesaian perkara di Mahkamah Agung dan badan peradilan di bawahnya, bukan berarti dapat dijalankan dengan tanpa ada halangan. Persoalan timbul manakala terbentur pada masalah domisili dari para pihak sebagaimana diatur pada Pasal 4 Ayat (3) di atas, yang menyebutkan bahwa Penggugat dan Tergugat harus berdomisili di daerah hukum Pengadilan yang sama. Hal inilah yang menjadi permasalahan di lapangan. Banyak para pencari keadilan yang terbentur dengan permasalahan domisili ini sehingga tidak dapat memanfaatkan mekanisme Gugatan Sederhana. Bila ditelaah, alasan domisili Penggugat dan Tergugat haruslah berdomisili hukum di daerah hukum pengadilan yang sama sesuai dengan ketentuan Peraturan Mahkamah Agung RI Nomor 2 Tahun 2015 tentang Tata Cara Penyelesaian Gugatan Sederhana di atas.

Pengaturan domisili para pihak yang harus dalam wilayah yang sama dalam perkara gugatan sederhana menjadi benturan dalam implementasi asas sederhana, cepat, dan biaya ringan dalam perkara gugatan sederhana pada sengketa bisnis. Pengaturan ini masih mengandung ketidakadilan, yaitu masih belum adanya kesamaan hak di depan hukum bagi para pencari keadilan yang berperkara dalam sengketa bisnis - termasuk bisnis syariah. Ketentuan ini dinilai sangat membatasi jika terdapat ketidaksamaan domisili hukum, maka para pihak tidak dapat menggunakan wadah gugatan sederhana ini. Sebagaimana pendapat Bimo Prasetyo, yang mengemukakan bahwa keharusan berdomisili pada wilayah yang sama dalam perkara gugatan sederhana, patut disayangkan lantaran hanya karena persoalan domisili menjadi batu ganjalan terhadap para pihak untuk menempuh mekanisme ini. Pendapat yang sama dikemukakan oleh Abdul Basith, yang mengemukakan bahwa persoalan domisili hukum yang mesti sama antara Penggugat dan Tergugat dikhawatirkan akan membatasi akses konsumen ketika ingin menggunakan mekanisme gugatan sederhana ini. 
Terkait dengan problem pengaturan persyaratan kesamaan domisili para pihak (Penggugat dan Tergugat) dalam gugatan sederhana pada sengketa bisnis - termasuk sengketa bisnis syariah - yang dinilai belum menjamin kesamaan hak diantara para pencari keadilan telah diamini oleh Hakim Agung Syamsul Ma'arif. Ia berpendapat bahwa persoalan domisili hukum para pihak berpeluang menggugurkan upaya penyelesaian sengketa menggunakan gugatan sederhana.

Menurut penulis, Peraturan Mahkamah Agung RI Nomor 2 Tahun 2015 tentang Tata Cara Penyelesaian Gugatan Sederhana yang dimaksudkan untuk memenuhi kebutuhan penyelenggaraan praktik peradilan dalam penyelesaian sengketa bisnis guna terwujudnya asas sederhana, cepat, dan biaya ringan ternyata belum mampu mewujudkan tujuan utama dikeluarkannya Peraturan Mahkamah Agung RI Nomor 2 Tahun 2015 tentang Tata Cara Penyelesaian Gugatan Sederhana tersebut.

Dari sisi keadilan, ketentuan para pihak harus dalam satu wilayah belumlah memberikan rasa keadilan bagi masyarakat. Seharusnya masalah domisili ini dapat diantisipasi dengan sebuah gebrakan nyata dimana masalah administrasi tentang Gugatan Sederhana ini diberikan sebuah keistimewaan dan didahulukan dari gugatan biasa sehingga permasalahan panggilan/relas keluar kota yang menjadi kendala dari proses Gugatan Sederhana dapat diantisipasi. Kalau selama ini pemanggilan/relas ke pengadilan lain menggunakan jalur surat menyurat yang memakan waktu lama ( \pm 3 minggu untuk relas luar kota), maka dalam panggilan Gugatan Sederhana dari Pengadilan Negeri tempat Gugatan Sederhana diajukan ke Pengadilan Negeri tempat domisili Tergugat dapat menggunakan e-mail (surat elektronik) sehingga tidak memerlukan waktu yang lama. Tetapi hal ini tentunya harus didukung oleh tenaga petugas pengadilan (Juru Sita) yang khusus menangani relas Gugatan Sederhana sehingga permasalahan mengenai domisili tersebut dapat diantisipasi sehingga Gugatan Sederhana dapat menjangkau para pihak yang berbeda domisili.

Berdasarkan uraian di atas, penulis berpendapat asas sederhana, cepat, dan biaya ringan belum dapat diwujudkan dalam pengaturan domisili para pihak dalam perkara gugatan sederhana sebagaimana Peraturan Mahkamah Agung RI Nomor 2 Tahun 2015 tentang Tata Cara Penyelesaian Gugatan Sederhana. Model penentuan yurisidiksi yang diadopsi dalam Peraturan Mahkamah Agung Nomor 2 Tahun 2015 tersebut berpotensi mengurangi tujuan hadirnya penyelesaian gugatan sederhana, yakni, memperluas akses pengadilan kepada masyarakat luas dan sebagai mekanisme penyelesaian yang didesain khusus bagi penyelesaian perkara-perkara kecil. Pembatasan yurisdiksi hanya pada satu domisili merupakan satu hal yang perlu ditinjau ulang di masa yang akan datang untuk lebih mendorong penggunaan mekanisme gugatan penyelesaian perkara di Indonesia. 


\section{Bentuk Formulasi \\ Pengaturan Kriteria Domisili Para Pihak pada Gugatan Sederhana dalam Sengketa Ekonomi Syariah}

Rumusan pengaturan kriteria domisili para pihak dalam gugatan sederhana perkara ekonomi syariah mengacu pada ketentuan Pasal 4 Ayat (3) Peraturan Mahkamah Agung RI Nomor 2 Tahun 2015 tentang Tata Cara Penyelesaian Gugatan Sederhana, "Penggugat dan Tergugat dalam gugatan sederhana berdomisili di daerah hukum pengadilan yang sama”.

Frasa para pihak haruslah berdomisili di daerah hukum pengadilan yang sama dinilai problematik dari segi landasan sosiologis dibutuhkannya pengaturan terkait dengan penyelesaian gugatan sederhana adalah akses terhadap keadilan (access to justice).

Akses terhadap keadilan didefinisikan sebagai :

"access by people, in particular form poor and disadvantaged group to fair, efective and accountable mechanism for the protection of rights, control of abuse of power and resolution of conflicts. This includes the ability of people to seek and obtain a remedy through formal and informal justice system, and the ability to seek and exercise infuence on law-making and lawimplementing processes and institutions".

Akses oleh masyarakat, secara khusus dari rakyat dan kelompok masyarakat lemah lainnya, terhadap mekanisme perlindungan atas hak yang adil, efektif, akuntabel, mekanisme tersebut dapat pula mengontrol kesewenang-wenangan dan menyelesaikan sengketa. Hal ini termasuk di dalamnya agar masyarakat dapat memperoleh keadilan melalui mekanisme hukum formal ataupun informal dan kemampuan dari masyarakat tersebut untuk mempengaruhi lembaga dan proses pembentukan hukum dan pelaksanaan hukum.

Mengacu pada tujuan adanya asas sederhana, cepat, dan biaya ringan dalam hukum acara perdata serta akses kepada keadilan diberikan agar masyarakat dapat menyelesaikan sengketa hukum yang ada secara adil dan efektif melalui mekanisme hukum gugatan sederhana sebagaimana diuraikan di atas, maka ketentuan domisili para pihak dalam Pasal 4 Ayat (3) Peraturan Mahkamah Agung RI Nomor 2 Tahun 2015 tentang Tata Cara Penyelesaian Gugatan Sederhana tersebut perlu diformulasikan kembali sehingga ketentuan tersebut dapat mengedepankan asas sederhana, cepat, dan biaya ringan yang mengandung nilai keadilan dan kemanfaatan.

Untuk reformulasi tersebut, penulis mengedepankan setidaktidaknya tiga landasan argumentasi, yakni landasan filosofis, landasan sosiologis dan landasan yuridis.

\section{Landasan Filosofis}

Peraturan perundang-undangan dikatakan mempunyai landasan filosofis (filisofische grondslag), apabila rumusannya atau normanya mendapatkan pembenaran jika dikaji secara filosofis. Jadi mendapatkan alasan sesuai dengan 
cita-cita dan pandangan hidup manusia dalam pergaulan hidup bermasyarakat dan sesuai dengan cita-cita kebenaran, keadilan, jalan kehidupan (way of life), filsafat hidup bangsa, serta kesusilaan.

Sebagaimana dikemukakan dalam uraian di atas, norma pengaturan domisili para pihak dalam gugatan sederhana pada sengketa bisnis - termasuk ekonomi syariah, mengharuskan para pihak berdomisili pada wilayah pengadilan yang sama, dinilai tidak berprespektif keadilan, karena membatasi gugatan sederhana pada para pihak yang berada di satu wilayah pengadilan yang sama. Hal ini sangat bertentangan dengan pengedepanan asas sederhana, cepat, dan biaya ringan bagi lembaga keuangan yang tidak memiliki kantor cabang di luar wilayah domisilinya.

Secara filosofis ketentuan

Pasal 4 Ayat (3) Peraturan Mahkamah Agung RI Nomor 2 Tahun 2015 tentang Tata Cara Penyelesaian Gugatan Sederhana, yang mengatur persyaratan "Penggugat dan Tergugat dalam gugatan sederhana berdomisili di daerah hukum pengadilan yang sama", diformulasikan menjadi :

\section{Pasal 4}

(a) Penggugat dan Tergugat dalam gugatan sederhana berdomisili di daerah hukum pengadilan yang sama;

(b) Apabila Para Pihak tidak berdomisili di daerah hukum yang sama, digunakan pemanggilan secara elektronik bagi pihak yang berada di luar wilayah pengadilan;
Nilai filosofis yang dikedepankan dalam formulasi rumusan tersebut dinilai lebih sesuai dengan cita-cita kebenaran dan keadilan. Rumusan tersebut mengandung pengertian gugatan sederhana tidak hanya membatasi domisili para pihak pada satu wilayah pengadilan yang sama, akan tetapi gugatan sederhana dapat digunakan oleh seluruh masyarakat, sedangkan untuk mengatasi kendala pemanggilan dapat digunakan sistem pengadilan melalui elektronik sebagaimana diatur dalam Pasal 14 Ayat (1) Peraturan Mahkamah Agung Nomor 3 Tahun 2018 tentang Administrasi Perkara Secara Elektronik di Pengadilan.

Suatu rumusan peraturan harus mencerminkan prinsip-prinsip pembentukan hukum yang adil, sebagaimana pendapat Lon Fuller, yang mengemukakan :

Prinsip-prinsip pembentukan hukum yang adil, diantaranya yaitu (a). Hukum-hukum harus dibuat sedemikian rupa sehingga dapat dimengerti oleh rakyat biasa. Fuller juga menamakan hal ini juga sebagai hasrat untuk kejelasan; (b). Aturan-aturan tidak boleh bertentangan satu sama lain; (c). Dalam hukum harus ada ketegasan. Hukum tidak boleh diubah-ubah setiap waktu, sehingga setiap orang tidak lagi mengorientasikan kegiatannya kepadanya; dan (d). Harus ada konsistensi antara aturan-aturan sebagaimana yang diumumkan dengan pelaksanaan senyatanya (Lon L. Fuller, 1964 : h. 39).

Apabila prinsip-prinsip tersebut dikaitkan dengan rumusan formulasi pengaturan domisili para 
pihak dalam gugatan sederhana pada sengketa bisnis - termasuk sengketa ekonomi syariah di atas, maka rumusan tersebut dinilai lebih tepat dan adil karena mengandung kejelasan rumusan, tidak bertentangan dengan aturan lain (baca : Peraturan Mahkamah Agung Nomor 3 Tahun 2018 tentang Administrasi Pengadilan Secara Elektronik di Pengadilan), adanya ketegasan, dan konsistensi.

\section{Landasan sosiologis}

Landasan sosiologis dalam pembentukan peraturan perundangundangan yaitu suatu peraturan perundang-undangan bisa dikatakan memiliki landasan sosiologis bila sesuai dengan keyakinan umum, kesadaran hukum masyarakat, tata nilai dan hukum yang hidup di masyarakat. Secara umum, landasan pembentukan peraturan perundangundangan harus berkaitan dengan kondisi atau kenyataan yang ada supaya peraturan yang dibuat dapat dijalankan.

Rumusan pengaturan domisili para pihak sebagaimana dalam Pasal 4 Ayat (3) Peraturan Mahkamah Agung RI Nomor 2 Tahun 2015 tentang Tata Cara Penyelesaian Gugatan Sederhana, dinilai sangat problematis dari sisi sosiologis, karena ketentuan tersebut sangat sulit dijalankan. Hal itu disebabkan karena tidak semua lembaga keuangan atau pihak yang bersengketa berdomisili pada satu wilayah pengadilan yang sama. Hal ini sudah tentu bertentangan dengan tujuan awal diterbitkannya Peraturan Mahkamah Agung RI Nomor 2 Tahun 2015 tentang Tata Cara
Penyelesaian Gugatan Sederhana, yaitu untuk mewujudkan asas sederhana, cepat, dan biaya ringan dalam penyelesaian sengketa bisnis termasuk bisnis syariah di pengadilan.

Formulasi pengaturan domisili para pihak sebagaimana dikemukakan di atas dinilai lebih sesuai dengan keyakinan umum, kesadaran hukum masyarakat, tata nilai dan perkembangan hukum yang hidup di masyarakat modern yang sudah mayoritas memanfaatkan teknologi informasi, dengan demikian cita-cita agar penyelesaian sengketa bisnis secara sederhana dapat dilaksanakan sesuai dengan asas sederhana, cepat, dan biaya ringan.

\section{Landasan yuridis}

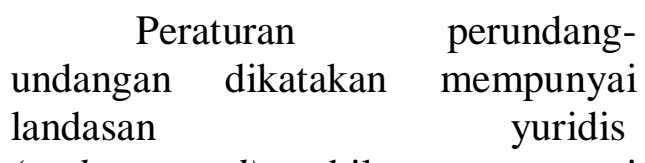

(rechtsground) apabila mempunyai dasar hukum, legalitas atau landasan yang terdapat dalam ketentuan hukum yang lebih tinggi derajatnya. Disamping itu landasan yuridis mempertanyakan apakah peraturan yang dibuat sudah dilakukan oleh atas dasar kewenganannya.

Formulasi pengaturan domisili para pihak dalam gugatan sederhana sebagaimana rumusan :

$$
\text { Pasal } 4
$$

(a) Penggugat dan Tergugat dalam gugatan sederhana berdomisili di daerah hukum pengadilan yang sama;

(b) Apabila Para Pihak tidak berdomisili di daerah hukum yang sama, digunakan pemanggilan secara elektronik 
bagi pihak yang berada di luar wilayah pengadilan;

Secara yuridis rumusan formulasi pengaturan domisili para pihak dalam gugatan sederhana tersebut lebih sesuai dan tidak bertentangan dengan peraturan lain yang berlaku, seperti Peraturan Mahkamah Agung Nomor 3 Tahun 2018 tentang Administrasi Perkara Secara Elektronik di Pengadilan.

Rumusan tersebut juga lebih sesuai dan lebih mengakomodir beberapa asas dalam pembentukan peraturan perundang-undangan. Diantaranya, asas pengayoman, yaitu materi muatan rumusan pengaturan tersebut berfungsi memberikan pelindungan untuk menciptakan ketentraman masyarakat. Asas kemanusiaan, rumusan tersebut mampu mencerminkan pelindungan dan penghormatan hak asasi manusia serta harkat dan martabat setiap warga negara dan penduduk Indonesia secara proporsional. Asas kebangsaan, rumusan tersebut mencerminkan sifat dan watak bangsa Indonesia yang majemuk dengan tetap menjaga prinsip Negara Kesatuan Republik Indonesia. Asas kekeluargaan, rumusan materi pengaturan domisili para pihak sebagaimana di atas, telah mencerminkan musyawarah untuk mencapai mufakat dalam setiap pengambilan keputusan. Asas kenusantaraan, bahwa rumusan tersebut senantiasa memperhatikan kepentingan seluruh wilayah Indonesia dan merupakan bagian dari sistem hukum nasional yang berdasarkan Pancasila dan UndangUndang Dasar Negara Republik Indonesia Tahun 1945.
Asas berikutnya yang dikedepankan dalam rumusan formulasi pengaturan domisili para pihak di atas, adalah asas bhinneka tunggal ika, yang memperhatikan keragaman penduduk, agama, suku dan golongan, kondisi khusus daerah serta budaya dalam kehidupan bermasyarakat, berbangsa, dan bernegara. Asas keadilan, rumusan tersebut mencerminkan keadilan secara proporsional bagi setiap warga Negara, tidak terbatas pada warga negara yang tinggal dalam satu wilayah pengadilan yang sama. Asas kesamaan kedudukan dalam hukum dan pemerintahan, rumusan tersebut dinilai tidak memuat hal yang bersifat membedakan berdasarkan latar belakang, antara lain, agama, suku, ras, golongan, gender, atau status sosial, termasuk domisili.

Asas ketertiban dan kepastian hukum, juga tercermin dalam rumusan formulasi di atas, yang dapat mewujudkan ketertiban dalam masyarakat melalui jaminan kepastian hukum. Serta asas asas keseimbangan, keserasian, dan keselarasan, yang mampu ditunjukkan oleh rumusan tersebut dengan mencerminkan keseimbangan, keserasian, dan keselarasan, antara kepentingan individu, masyarakat dan kepentingan bangsa dan negara.

Berdasarkan uraian di atas, maka bentuk formulasi pengaturan kriteria domisili para pihak pada gugatan sederhana dalam sengketa bisnis termasuk sengketa ekonomi syariah, sebagaimana termuat dalam Pasal 4 Ayat (3) Peraturan Mahkamah Agung RI Nomor 2 Tahun 2015 tentang Tata Cara 
Penyelesaian Gugatan Sederhana, dapat dirumuskan sebagai berikut :

\section{Pasal 4}

(a) Penggugat dan Tergugat dalam gugatan sederhana berdomisili di daerah hukum pengadilan yang sama;

(b) Apabila Para Pihak tidak berdomisili di daerah hukum yang sama, digunakan pemanggilan secara elektronik bagi pihak yang berada di luar wilayah pengadilan;

\section{KESIMPULAN}

Dari uraian pembahasan di atas, maka dapat diambil kesimpulan sebagai jawaban atas rumusan masalah dalam kajian ini, yaitu :

1. Keterkaitan asas sederhana, cepat, dan biaya ringan dengan perkara gugatan sederhana dalam sengketa ekonomi syariah adalah sistem penyelesaian melalui acara sederhana dalam sengketa ekonomi syariah merupakan salah satu bentuk implementasi asas sederhana, cepat, dan biaya ringan dalam penyelenggaraan peradilan pada sengketa ekonomi syariah, begitu pula sebaliknya asas sederhana, cepat, dan biaya ringan dapat diwujudkan dalam penyelesaian sengketa ekonomi syariah melalui sistem penyelesaian gugatan sederhana (small claim court).

2. Asas sederhana, cepat, dan biaya ringan belum dapat diwujudkan dalam pengaturan domisili para pihak dalam perkara gugatan sederhana sebagaimana Peraturan Mahkamah Agung RI
Nomor 2 Tahun 2015 tentang Tata Cara Penyelesaian Gugatan Sederhana. Model penentuan yurisidiksi yang diadopsi dalam Peraturan Mahkamah Agung Nomor 2 Tahun 2015 tersebut berpotensi mengurangi tujuan hadirnya penyelesaian gugatan sederhana, yakni, memperluas akses pengadilan kepada masyarakat luas dan sebagai mekanisme penyelesaian yang didesain khusus bagi penyelesaian perkara-perkara kecil. Pembatasan yurisdiksi hanya pada satu domisili merupakan satu hal yang perlu ditinjau ulang di masa yang akan datang untuk lebih mendorong penggunaan mekanisme gugatan penyelesaian perkara di Indonesia.

3. Bentuk formulasi pengaturan kriteria domisili para pihak pada gugatan sederhana dalam sengketa bisnis termasuk sengketa ekonomi syariah, sebagaimana termuat dalam Pasal 4 Ayat (3) Peraturan Mahkamah Agung RI Nomor 2 Tahun 2015 tentang Tata Cara Penyelesaian Gugatan Sederhana, dapat dirumuskan sebagai berikut :

(a) Penggugat dan Tergugat dalam gugatan sederhana berdomisili di daerah hukum pengadilan yang sama;

(b) Apabila Para Pihak tidak berdomisili di daerah hukum yang sama, digunakan pemanggilan secara elektronik bagi pihak yang berada di luar wilayah pengadilan. 


\section{DAFTAR PUSTAKA}

A. Buku-Buku

Abdul R. Saliman, Hukum Bisnis Untuk Perusahaan : Teori Dan Contoh Kasus, Edisi Kelima, (Jakarta : Kencana Prenada Media, 2005)

Abdulkadir Muhammad, Hukum dan Penelitian Hukum, (Bandung : PT. Citra Aditya Bakti, 2004)

Achmad Ali dan Wiwie Heryani, Menjelejahi Kajian Empiris Terhadap Hukum, (Jakarta : Kencana Prenadamedia Group, 2012)

Achmad Ali, Menguak Tabir Hukum, (Jakarta : Chandra Pratama, 1996)

Amran Suadi, Penyelesaian Sengketa Ekonomi Syariah, Penemuan dan Kaidah Hukum, (Jakarta : Kencana Prenada Media Group, 2018)

Amran Suadi, Penyelesaian Sengketa Ekonomi Syariah: Teori dan Praktek, (Jakarta: Kencana, 2017), Cet. Ke-2

Bambang Waluyo, Penelitian Hukum dalam Praktik, (Jakarta : Sinar Grafika, 1991)

Bernard L. Tanya, Politik Hukum Agenda Kepentingan Bersama, (Yogyakarta : Genta Publishing, 2011)

Dimas Prasidi, dkk, Pembatasan Perkara : Strategi Mendorong Peradilan Cepat, Murah, Efisien dan Berkualitas, (Jakarta : Leip, 2010)

Efa Laela Fakhriah, Mekanisme Penyelesaian Sengketa
Bisnis yang Efektif dan Efisien, (Bandung : Keni, 2012)

Lon L. Fuller, Morality of Law, (New Haven and London : Yale University Press, 1964)

M. Hatta Ali, Peradilan Sederhana, Cepat, dan Biaya Ringan Menuju Keadilan Restoratif, (Bandung : PT. Alumni, 2012)

M. Yahya Harahap, Beberapa Tinjauan mengenai Sistem Peradilan dan Penyelesaian Sengketa, (Bandung : PT. Citra Aditya Bakti, 1997)

Ridwan Mansyur dan D.Y. Witanto, Gugatan Sederhana Teori, Praktik dan Permasalahannya, Cet. I, (Jakarta : Pustaka Dunia, 2017)

The World Bank, IFC, Kementerian Negara Pendayagunaan Aparatur Negara, et all, Small Enterprise Development Policies in Indonesia : An Overview, dalam The Internasional Finance Corporate Indonesia, Doing Business in Indonesia 2012 A Copublication of The World Bank and The International Finance Corporation, (Washington : IFC-World, 2012)

\section{B. Peraturan Perundang- Undangan}

Peraturan Mahkamah Agung R.I. Nomor 14 Tahun 2016 tentang Tata Cara Penyelesaian Sengketa Ekonomi Syariah. 
Peraturan Mahkamah Agung R.I.

Nomor 2 Tahun 2015 tentang

Tata Cara Penyelesaian

Gugatan Sederhana.

Peraturan Mahkamah Agung R.I.

Nomor 3 Tahun 2018 tentang

Administrasi Perkara di

Pengadilan Secara Elektronik.

Undang-Undang Dasar Negara

Republik Indonesia Tahun

1945

Undang-Undang Nomor 48 Tahun

2009 tentang Kekuasaan

Kehakiman

Undang-Undang Nomor 7 Tahun 1989 tentang Peradilan Agama

Undang-Undang Nomor 3 Tahun 2006 tentang Perubahan atas Undang-Undang Nomor 7

Tahun 1989 tentang Peradilan

Agama 